\title{
THE ECO-SYSTEM, BARRIERS AND FACTORS OF SUSTAINABLE GROWTH SOCIAL ECONOMY IN ARMENIA
}

\begin{abstract}
ANNA MALKHASYAN
The most important issues facing Armenia are poverty and unemployment. 30 percent of the population still lives under the national poverty line ( $\$ 3.3$ per capita per day) $)^{1}$. More than one in three respondents in the 2017 Caucasus Barometer indicated that unemployment, at 18 percent in $2017^{2}$. Half of Armenian youth and adults lack a job. Both men and women with post-graduate education are unlikely to stay unemployed. Female youth unemployment slightly exceeded male rates in groups with vocational education $(16.5 \%$ of females against $14.3 \%$ of males) ${ }^{3}$.

The "Velvet Revolution" in 2018 brought change and, most importantly, raised the perceptions about job prospects, especially among youth. The Program of the new government, adopted in February 2019, prioritizes job creation through entrepreneurship, innovation, improved investment climate, exports, and enhanced human capital potential. The government is also in the process of developing the new Labor Market Strategy 2019-2024 and recently launched the Work, Armenia! initiative to coordinate efforts to promote employment by different ministries, government agencies, educational institutions, and employers ${ }^{4}$.
\end{abstract}

At the international level the idea of social entrepreneurship has gained importance in the early 90ths. There is a bulk of evidence demonstrating the significant role of social entrepreneurship in promoting resilient, and sustainable society. By adhering to the ideas of social inclusiveness and innovation, social enterprises have proven their abilities in overcoming multiple social-economic challenges and absorbing system crises.

Despite the increasing number of social enterprises in Armenia, it is still highly challenging to measure the growth and potential of the social economy

\footnotetext{
${ }^{1}$ See: UN, SDG implementation voluntary national review, 2018, https://sustainabledevelopment.un.org/content/documents/19586Armenia VNR 2018.pdf

${ }^{2}$ See: Caucasus Barometer, The annual household survey about social economic issues and political attitudes (Georgia and Armenia), 2018, https:/caucasusbarometer.org/en/cb2017/factsheet/.

${ }^{3}$ See: Save the Children, Youth-focused and gender-sensitive labor market research in Armenia, 2018, https://armenia.savethechildren.net/sites/armenia.savethechildren.net/files/library/ LMR\%20Report_Eng.pdf

${ }^{4}$ See: World Bank, Work for a better future in Armenia: an analysis of jobs dynamics, 2019, http://documents.worldbank.org/curated/en/387401564380250230/pdf/Work-for-a-betterfuture-in-Armenia-An-analysis-of-jobs-dynamics.pdf
} 
sector of Armenia. Lack of state recognition and comprehensive database hinder the possibility of capturing the whole spectrum of existing social enterprises in the country. As it was stated in the 2018 Civil Society Organization Sustainability Index report for Armenia ${ }^{5}$, there were 4222 public organizations, 1120 foundations, and 244 legal entity unions registered in Armenia as of the end of 2018, out of which around 240 are associated with entrepreneurship activities. However, it is difficult to track whether they meet the criteria inherent to social enterprises. Moreover, not all of the SEs are registered as separate entities - in some cases, they are running as a project of non-governmental organizations. De-facto, there are also social enterprises that are 'hidden' among other existing legal forms, notably amongst cooperatives, individual enterprises, and limited liability companies. In the experts' view ${ }^{6}$, there are around 100 SEs, already established in Armenia. A very few enterprises operating in Yerevan, around $80-85 \%$ are located in the regions. Most of the enterprises are still not at a level of self-sufficiency, operational efficiency, and sophistication as comparable commercial businesses in the country. It is also problematic to obtain a statistically robust picture of what social enterprises do.

According to expert estimations, from a chronological point of view, Armenian social enterprises are at the initial stage of development. Existing social businesses have approximately 3-5 years of experience, on average. Armenian social enterprises are mainly concentrated in specific niches - notably in agriculture, tourism, crafts, and arts sectors.

\section{Enabling environment for social enterprises}

The features of enabling environment for social enterprise - necessary to overcome challenges to growth - tend to be slowly emerging in Armenia. The conceptualization of a social enterprise eco-system is based on commonly recognized features able to contribute to providing an enabling environment for social enterprise ${ }^{7}$.

It is worth noting that some features of a well-known scheme changed since not all elements are existing in the country and/or applicable to our context. The following subsections summarize the current state of development of these characteristics.

${ }^{5}$ See: 2018 Civil Society Organization Sustainability Index, For Central and Eastern Europe and Eurasia, 2019, https://www.fhi360.org/sites/default/files/media/documents/resourcecsosi-2018-report-europe-eurasia.pdf

${ }^{6}$ The analysis presented in the article is based on market assessment results, conducted in April-May, 2020, in the framework of EU funded "Social entrepreneurship in Georgia and Armenia project", implemented by Mercy Corps jointly with regional partners - the Association of Business Consulting Organisations of Georgia and Development Principles, Armenian NGO. In the article, only the desk review and qualitative survey results are presented. For more details see: http://www.developmentprinciples.org/news/17?fbclid=IwAR2-bFxO50QUyhV0gtTzm 7XtptfJOpou5VYquKZLvC11ZnRolhqIHIXsJ04

${ }^{7}$ See: European Commission, A map of social enterprises and their ecosystems in Europe, 2014, http://ec.europa.eu/social/main.jsp 


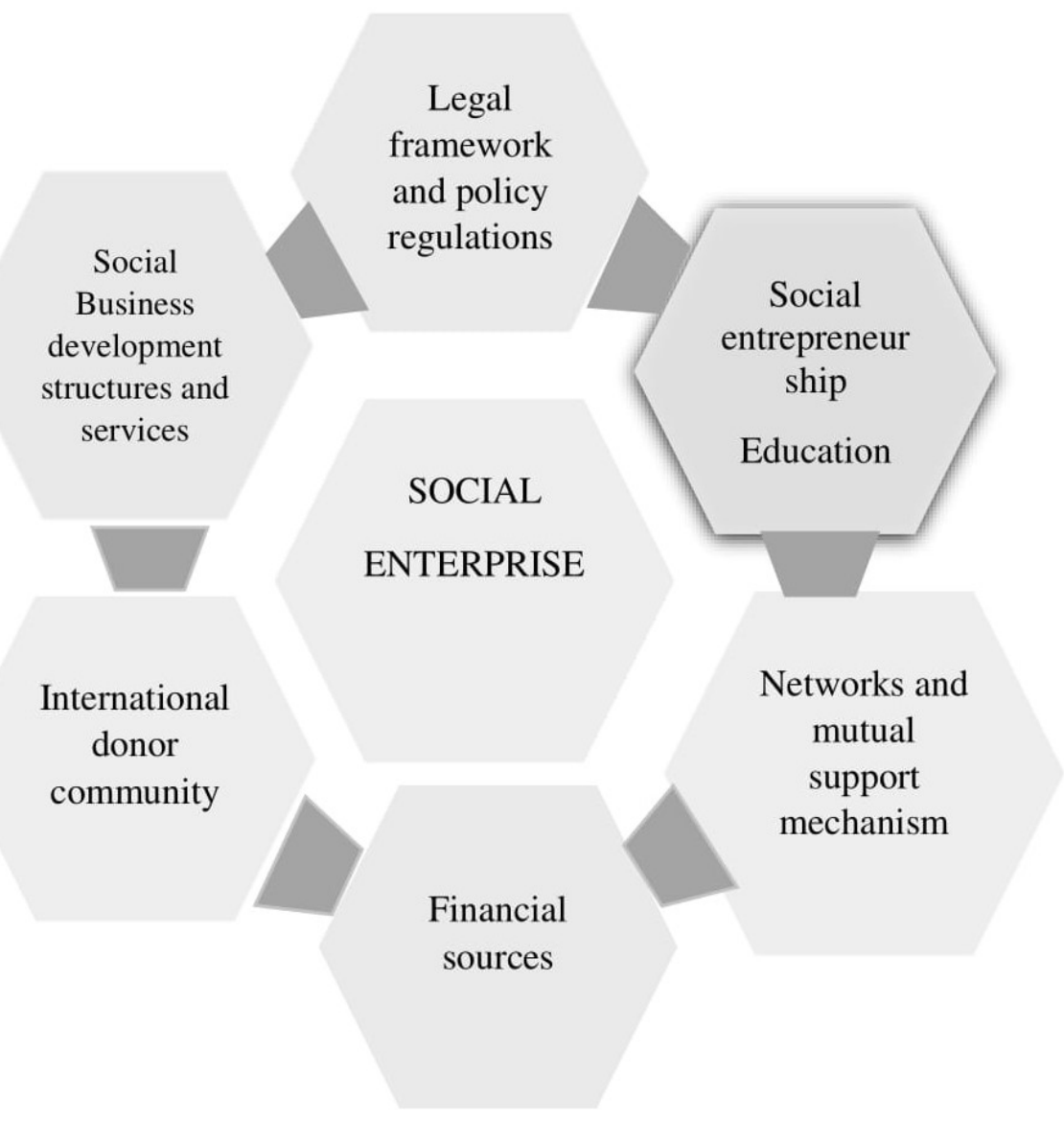

\section{The role of the International donor community}

In Armenia, the development of the social economy was mostly fueled by the availability of donor funds for this purpose. There are a lot of representations and branches of international organizations that implement diverse grant projects to foster the social economy sector growth. The European Delegation and USAID are the key players in the field, that have made significant investments in developing social entrepreneurship in the country during recent years. By promoting this sector growth, the international organizations mainly aim at creating favorable conditions for local CSOs to become a selfreliant and sustainable organization and/or to increase employability and ensure income generation opportunities for vulnerable social groups. The prominent role of the donor community in developing this sector is undeniable. However, more donor cooperation is needed to increase coordination and avoid duplicities of the projects. 


\section{Networks and social business support structures}

The role of social business support structures is indispensable in the development of sustainable business models. Various incubators and business support structures have been emerging during recent years in Armenia. However, only a very few directly address issues of social enterprises and act as networking, experience exchange platforms, promote the visibility of the field, and educational opportunities for social entrepreneurs. The Association of Social Enterprises of Armenia (ASEA) and Impact Hub Yerevan (IHY) are the main actors in this regard. However, they are still in the initial stage of development. Currently, the Association involves around 50 members, including both social business entities and individuals. It operates on a volunteer basis. Structural and operational changes are required to ensure the sustainability and effectiveness of the Association. In the experts' view, to sustain itself, the Association could become a social enterprise itself to generate resources for the field development and become a financially viable structure. Impact Hub demonstrates itself as an effective operational model of SE. Around 70\% of funding sources of IHY are generated through entrepreneurship activities. Currently, there are around 230 members in IHY, It unites not only social enterprises but also various local and international experts. It could cooperate more with Association, EU, and different business structures within its different acceleration or value-added programs.

\section{Access to finance, legal regulations, and policies}

Like any other form of business, social enterprises need to diversify their financial flows to expand their business operations. The experts highlighted that social enterprises in Armenia face serious obstacles to access finance. There are no financial institutions in place to offer financial products and services specifically tailored for social businesses. Existing banks and microfinance institutions offers business support or individual loans with a very high-interest rate (varying from $12 \%$ to $20 \%$ ).

There is still no specific legislation in place regulating the social entrepreneurship sector in Armenia. However, most of the experts denied the need for having a separate law on social enterprise at this stage of social entrepreneurship development in the country. Their main concern is related to potential risks of increasing of unethical and corruptive practices among traditional business entities, which might try to get registered as "social enterprises" and gain all advantages or tax privileges stipulated by law without ensuring any social impact. This situation could significantly drag backward overall sector development and negatively effects on attitudes of the general public toward the idea of social entrepreneurship.

Meantime, recently, due to the efforts of the sector representatives, the Social entrepreneurship development concept ${ }^{8}$ has been drafted and now at the

\footnotetext{
${ }^{8}$ See: https://www.e-draft.am/projects/1180/about
} 
stage of circulation and discussion with the government. Most of the experts agreed that acceptance of the "Social entrepreneurship development concept" by the State is of critical importance for the sector growth. The document provides definition and criteria for specification of social entrepreneurship activities, suggests the criteria for distinguishing social enterprise from any other business or non-profit organizations:

In 2014, the Ministry of Justice of the Republic of Armenia developed and put into circulation a new legislative bill regulating the entrepreneurial activity of the NGO, which was adopted in December 2016 . Article 8 (1) of the amended version of the Law on Non-Governmental Organizations stipulates that NGOs can directly engage in entrepreneur activities. However, paragraphs 2 and 3 of the same article stipulate that the organization must keep separate financial records of business activities, including information on it in the reports stipulated by law, and use the profits only for the statutory purposes of the organization ${ }^{10}$. According to experts, in reality, these changes in law do not help NGOs to handle their financial issues, instead, they imply tighter control of NGOs by government agencies.

\section{Education}

Entrepreneurship education plays a crucial role in developing the social entrepreneurship sector in the country. There are a few, but important initiatives have been already undertaken at private and public levels in this regard. To promote entrepreneurial knowledge and skills among Armenian school graduates, the compulsive subject "entrepreneurship education" was piloted in several schools of Armenia. Following its results, in 2017, the RA Ministry of Education and Science jointly with the "Junior Achievement of Armenia" NGO incorporated a component of business education in the subject of "Technology" from 2-10th grade, also in the 11th grade as a practical component. ${ }^{11}$ What comes to the higher education system, entrepreneurship education is rather promoted through universities' extension programs and different incubators and centers located within universities than through academic curricula.

Among private initiatives that contribute specifically to the development of social entrepreneurship in Armenia, it is worth highlighting a recently established (2018) School of Social Entrepreneurs. The school provides basic education for those who plan to start up a social business. Thus the School of Social Entrepreneurs not only promotes the dissemination of SE education but also supports business ideas and initiatives. ${ }^{12}$

Barriers and limitation of development of social entrepreneurship

\footnotetext{
${ }^{9}$ See: the same as above

${ }^{10}$ See: https://www.arlis.am/DocumentView.aspx?docID $=110802$

11 See: Youth entrepreneurship in eastern partnership countries: the way forward, 2018, http://eapcsf.eu/wp-content/uploads/YOUTH_ENTREPRENEURSHIP_IN_EAP_THE_WAY_FORWARD.pdf

${ }^{12}$ See: https://www.facebook.com/Schoolofsocialentrepreneurs/
} 
Each social business faces its specific constraints, however, several common ones, hampering overall sector growth, were summarized by the experts as follows:

- Misunderstanding and poor awareness about social entrepreneurship: poor recognition of social enterprise concept among the general public, policymakers, investors, costumes, etc. Lack of criteria for differentiation and acknowledgment of the added value created by social enterprises. Perception of social business as a charity, corporate social responsibility, or integration of disabled people in the job market.

- Absence of a unified bank of information: no unified database and information of social enterprises exist in the country. It is difficult to quantify the current size, track, and analyze the dynamics of the sector development.

- Lack of Aggregated Impact measurement system: SEs in Armenia are not engaged in proper social impact measurement and reporting, making it difficult for them to gain evidence of their real social impact.

- Insufficient business support infrastructure and services: mentoring and consultancy schemes, diverse special incubators and peer support groups and networks are under-developed in the country. Although social business passes the same stages of development as any other business, and their needs are mostly the same, they have some peculiarities that require tailored approaches.

- Insufficient diversification of financial sources: special financial products for social enterprises are non-existent in Armenia. Social businessoriented investment and financing system is under-developed.

- Lack of access to markets: many social enterprises are constrained when it comes to access to the market, even if they do have a product that is in demand. There are various reasons for this lack of access - the SE could be geographically far from the market or could have no resources or skills to penetrate this market well.

- Skills and management: most SE founders are NGO sphere people who have limited business skills and mindset. There is a serious problem with the business and financial planning and literacy. In many cases, the founders do not hire a professional CEO.

- Poor education system: there are limited opportunities to get a professional education in this field. Nation-wide education system on social entrepreneurship is under-developed. Social entrepreneurship is very poorly addressed in existing academic curricula and programs.

- The dependency on donor funds: donors' support is considered as the main source of funding by SEs. However, according to the experts, the dependency on grants used to result in business degradation after these funding sources exhausted.

- Lack of coordination: despite the increasing number of different 
stakeholders, services, and initiatives, there is an obvious lack of coordination and in some cases duplication of efforts by different activities. No specific structure exists, addressing social entrepreneurship-related policies, plans, and activities.

\section{Conclusions and recommendation for the sustainable growth of the social economy sector}

The idea of social enterprises becomes quite popular during recent years in Armenia. Despite a growing number of such forms of organizations, it remains highly challenging to measure the growth and potential of social enterprises in Armenia, given the fact that most of such initiatives take place 'under the radar'.

In Armenia the development of the social economy was mostly promoted by the availability of donor funds for this purpose. Although the donor community plays a critical role in boosting the sector developing and promoting the culture of social entrepreneurship in the country, consistent dependency on donor funding results in the degrading of social businesses. Meanwhile, international experience demonstrates other ways of doing social businesses. Most SE founders are NGO sphere people, who often lack the appropriate business skills and mentality. There is a serious problem with the business and financial planning and literacy. In many cases, the founders do not hire a professional CEO. The trend seems to be that as SEs become an increasingly popular concept, CSOs create an SE component without proper market research, without a viable business model, and without knowledge of the market or industry.

There are limited opportunities to get a professional education in this field. Nation-wide education system on social entrepreneurship is under-developed. Social entrepreneurship is very poorly addressed in existing academic curricula and programs.

Diverse business support services and incubators have been emerging during recent years in Armenia. However, only a very few directly address issues of social enterprises and act as networking, experience exchange platforms, promote the visibility of the field, and educational opportunities for social entrepreneurs. There are no financial institutions in place to offer financial products and services specifically tailored for social businesses. There is still no specific legislation and policy in place regulating the social entrepreneurship sector in Armenia.

Increasing visibility and recognition of the social entrepreneurship concept at the state level. All experts have acknowledged that the promotion of the concept of social entrepreneurship by the state will be an important step forward in the institutionalization of the social entrepreneurship system in Armenia. It is also necessary to include the social economy sector in the national strategies and plans combating against unemployment and poverty and create a 
unified database on existing organizations, specifying their characteristics and diverse business models. It will allow identify best practices, replicable models, and enable discussion on lessons learned.

Promoting social business support services. It is important to develop a broad variety of business development services and support schemes specifically designed for social enterprises and social economy, such as exchange platforms, diverse consultancy and mentoring services, peer support networks. These structures should operate permanently and provide SEs with support at all stages of their development.

Skills and leadership. There is a need to develop business and finance skills among social entrepreneurs. New schemes of cooperation among entrepreneurs should also be promoted. According to the experts, it will be useful to involve in the social economy sector representatives of traditional businesses through their partial share and ownership in social businesses. The best option is creating coalitions including representatives from both traditional business and CSO sectors. Such forms of cooperation will compensate and balance the lack of business skills and mindset among the majority of representatives of social businesses.

Education. There should be pilot laboratories in institutes, schools, colleges. Social Entrepreneurship should find its place in the formal education system.

Diversification of financial sources. Social Impact investment system should be promoted in the country. Multiple schemes are possible. Among different models, experts suggest, for instance, large business entities to donate amounts for SEs within their corporate social responsibility. They also pinpointed the important role of Armenian Diaspora in terms of investments in the sector. To ensure organizational development and sustainability of social businesses mixed financial schemes could be employed, including grants and loans, provided together in different combinations. New credit products for SEs with favorable terms or/and flexible credit payment schedules should be created.

Donor support. It is of paramount importance to set new approaches and standards at the grantee selection stage. Not only CSOs should be eligible to establish social enterprises. The involvement of business entities and the private sector might be encouraged. More support for social enterprises at scale-up levels could be provided.

Coordination and synergy. More horizontal coordination is needed among different structures and initiatives to avoid duplicities and ensure more addressed support to social enterprises.

Key words - social entrepreneurship, incubator, business support structure, sustainability, diversification, social economy, network 


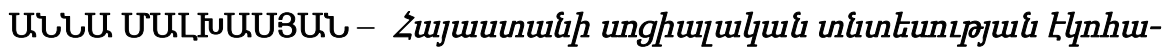

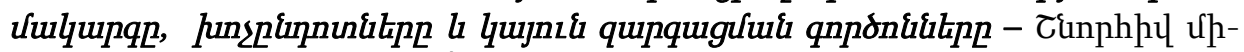

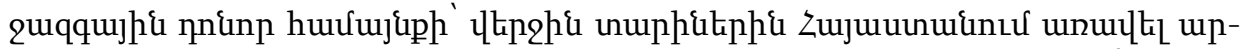

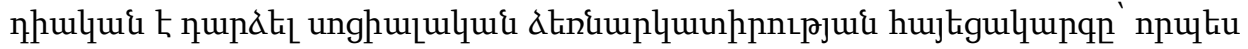

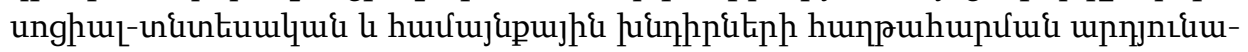

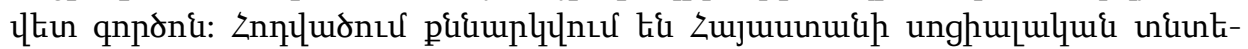

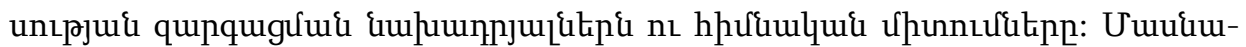

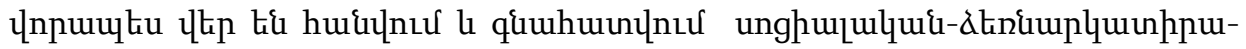

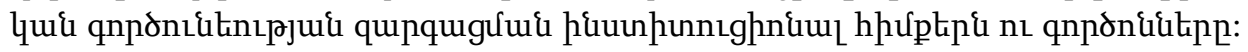

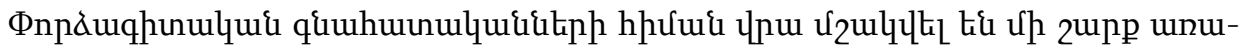

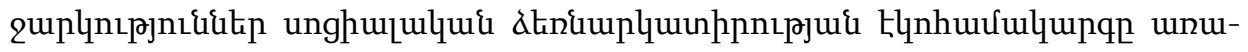

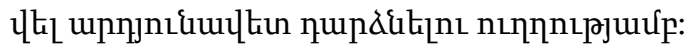

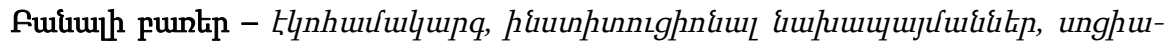

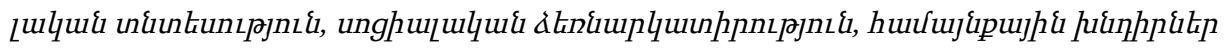

АННА МАЛХАСЯН - Эко-система, ограничения и факторы устойчивого развития социальной экономики Армении. - Благодаря международному донорскому сообществу в последние годы концепция социального предпринимательства стала в Армении фактором регулирования социально-экономических и локальных проблем. В статье рассмотрены основные тенденции развития социальной экономики. В частности, проанализированы институциональные аспекты и факторы развития социального предпринимательства. На основе экспертных оценок разработаны рекомендации по более эффективному развитию экосистемы социального предпринимательства.

Ключевые слова: экосистема, сочиальное предпринимательство, социальная экономика, институциональные предпосылки

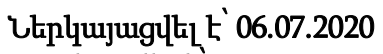

Qpupunultil to 09.09.2020

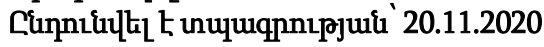




\begin{abstract}
Thanks to the international donor community, in recent years, the concept of social entrepreneurship has become a factor in the regulation of socio-economic and local problems in Armenia. The article examines the main trends in the development of the social economy. In particular, the author analyzes the institutional aspects and factors of the development of social entrepreneurship. On the basis of expert assessments, recommendations have been developed for a more effective development of the ecosystem of social entrepreneurship.
\end{abstract}

Keywords: social entrepreneurship, incubator, business support structure, sustainability, diversification, social economy, network

\title{
About Authors
}

Anna Malkhasyan - Lecturer of the Chair of Applied Sociology, Yerevan State University E mail: annamalkhasyan@yahoo.com

\section{REFERENCES}

UN, SDG implementation voluntary national review, 2018, https://sustainabledevelopment.un.org/content/documents/19586Armenia_VNR_2018.pdf Caucasus Barometer, The annual household survey about social economic issues and political attitudes (Georgia and Armenia), 2018, https://caucasusbarometer.org/en/cb2017/factsheet/.

Save the Children, Youth-focused and gender-sensitive labor market research in Ar-menia, 2018 , https://armenia.savethechildren.net/sites/armenia.savethechildren.net/files/library/LMR\%20 Report_Eng.pdf

World Bank, Work for a better future in Armenia: an analysis of jobs dynamics, 2019, http://documents.worldbank.org/curated/en/387401564380250230/pdf/Work-for-a-betterfuture-in-Armenia-An-analysis-of-jobs-dynamics.pdf

2018 Civil Society Organization Sustainability Index, For Central and Eastern Europe and Eurasia, 2019, https://www.fhi360.org/sites/default/files/media/documents/resource-csosi2018-report-europe-eurasia.pdf

The analysis presented in the article is based on market assessment results, conducted in April-May, 2020, in the framework of EU funded "Social entrepreneurship in Georgia and Armenia project", implemented by Mercy Corps jointly with regional partners - the Association of Business Consulting Organisations of Georgia and Development Principles, Armenian NGO. In the article, only the desk review and qualitative survey results are presented. For more details, see: http://www.developmentprinciples.org/news/17?fbclid=IwAR2-bFxO50QUyhV0gtTzm 7XtptfJOpou5VYquKZLvC11ZnRolhqIHIXsJ04

European Commission, A map of social enterprises and their ecosystems in Europe, 2014, http://ec.europa.eu/social/main.jsp 
Youth entrepreneurship in eastern partnership countries: the way forward, 2018, http://eapcsf.eu/wp-

content/uploads/YOUTH_ENTREPRENEURSHIP_IN_EAP_THE_WAY_FORWARD.pdf 